\title{
Impact of the Tsunami on healthcare systems
}

\author{
M Carballo S Daita M Hernandez
}

J R Soc Med 2005;98:390-395

The Tsunami that hit countries in the Indian Ocean killed over 180000 people, left some 50000 others missing and presumed dead, and displaced more than 1.6 million 'survivors'. ${ }^{1}$ Coastal regions and island infrastructures in the affected countries were so damaged that many of the economic, social and health gains that had been achieved in recent years were lost and hundreds of thousands of people were pushed back or further into poverty.

Natural and man-made disasters damage the infrastructure of countries in many ways. One of the consequences of the December 2004 Tsunami concerned the healthcare sector, which was affected more than some other sectors because of the loss of scarce human as well as physical resources. The effects of the Tsunami varied with factors including the physical geography of the region, the force of the waves when they hit the shore, and the extent to which the waves penetrated the shoreline. Although the disaster prompted a massive relief operation by the affected countries and the international community, several key challenges emerged and remain unresolved - in particular, the ways in which the health sector should prepare for future natural disasters. These include intersectoral cooperation, infrastructural preparedness, and sensitivity to local knowledge.

\section{DAMAGE TO HEALTHCARE SERVICES}

Table 1 gives an idea of the health situation and number of healthcare personnel in the affected countries before the disaster. In Indonesia, the most severely hit of the countries, the Tsunami destroyed 30 health clinics out of 240 , seriously damaged 77 , and caused minor damage to an additional $40 .^{2}$ The loss of health personnel was also substantial, and for a country that already had a low number of physicians, nurses and midwives, the deaths (or still missing status) of as many as 700 out of 9800 health

International Centre for Migration and Health, Route du Nant d'Avril, $\mathrm{CH}-1214$ Vernier (Ge), Switzerland

Correspondence to: Dr Manuel Carballo, Executive Director, ICMH workers constituted a serious blow to the healthcare system and those it served. ${ }^{3}$ The fact that $30 \%$ of all midwives in the region died or are still missing is already compromising safe motherhood and newborn care. ${ }^{4}$

In the Maldives, where the average land altitude is about $1.5 \mathrm{~m}$ above sea level and where at least a third of the country's population was affected by the Tsunami, many healthcare facilities suffered badly. ${ }^{1}$ On some of the islands that were hit (not all islands were affected), clinics and hospitals lost all their equipment including heavy X-ray machines and generators. ${ }^{4}$ Computers and printed files were also lost and the health records with them. Personnel losses were also proportionately high because many specialized medical personnel were expatriates from India and Sri Lanka. Some were on vacation and did not return; others felt the need to go back to be with their families. ${ }^{1}$

Healthcare facilities along the affected coast in Thailand suffered severely but there were, nevertheless, a sufficient number of proximate hospitals not far inland that were able to take up the patient load. In Ranong and Phang-Nga Provinces, 7 public health officers and 25 public health volunteers died and 6 public health centres (PHCs) were badly damaged. ${ }^{6}$ Elsewhere three PHCs were heavily damaged in Phuket Province and in Krabi Province, and the Phi Pho Hospital and 18 public health centres suffered considerably. In Sri Lanka, it is estimated that over $17 \%$ of all curative care institutions were severely damaged, ${ }^{6}$ but as in Thailand the presence of other healthcare facilities not far inland, together with a large population of trained healthcare staff, meant that patient loads could be shared.

The magnitude of the Tsunami's economic impact on the region's healthcare systems was also great, especially since the costs of reconstruction will often have to be borne by provincial governments (Table 2).

In Indonesia, the World Bank estimates that the losses incurred by the health sector amounted to around $\$ 91.9$ million and the expectation is that $\$ 131.14$ million will be required for reconstruction of the health facilities. ${ }^{7,8}$ Losses incurred in Sri Lanka exceeded $\$ 60$ million and the costs of reconstruction will be around $\$ 84$ million. ${ }^{9}$ Health sector damage in India amounted to $\$ 15.7$ million and the costs of 
Table 1 Pre-disaster health and health personnel [Source: WHO, World Health Statistics 2005-Data on Singapore and Switzerland included for comparative purposes only]

\begin{tabular}{|c|c|c|c|c|c|c|c|c|c|c|c|c|}
\hline \multirow[b]{2}{*}{ Country } & \multicolumn{2}{|c|}{ Infant mortality } & \multicolumn{2}{|c|}{ Maternal mortality } & \multicolumn{2}{|c|}{ No. of physicians } & \multicolumn{2}{|c|}{$\begin{array}{l}\text { No. of nurses } \\
\text { and midwives }\end{array}$} & \multicolumn{2}{|c|}{$\begin{array}{l}\text { No. of health } \\
\text { workers }\end{array}$} & \multicolumn{2}{|c|}{ Hospital beds } \\
\hline & $\begin{array}{l}\text { Per } \\
1000\end{array}$ & Year & $\begin{array}{l}\text { Per } 100000 \\
\text { live births }\end{array}$ & Year & $\begin{array}{l}\text { Per } \\
10000\end{array}$ & Year & $\begin{array}{l}\text { Per } \\
10000\end{array}$ & Year & $\begin{array}{l}\text { Per } \\
10000\end{array}$ & Year & $\begin{array}{l}\text { Per } \\
10000\end{array}$ & Year \\
\hline India & 64.0 & 2004 & 540 & 2000 & 5.9 & 2003 & 7.9 & 2003 & 13.8 & 2003 & 1.3 & 2003 \\
\hline Indonesia & 39.5 & 2000 & 230 & 2000 & 1.1 & 1998 & 4.9 & 2000 & 6.0 & $98 / 00$ & 4.5 & $98 / 20$ \\
\hline Maldives & 38.3 & 2000 & 110 & 2000 & 8.4 & 2000 & 12.3 & 2000 & 20.7 & 2000 & 1.5 & 2000 \\
\hline Malaysia & 12 & $95-00$ & 41 & 2000 & 7.0 & 2000 & 18.1 & 2002 & 25.1 & 2002 & 19 & 2001 \\
\hline Myanmar & 91 & $95-00$ & 360 & 2000 & 3.0 & 2000 & 4.8 & 2000 & 7.8 & 2000 & 6 & 2000 \\
\hline Somalia & 133 & $95-00$ & 1100 & 2000 & 0.4 & 1997 & 2.0 & 1997 & 2.4 & 1997 & 4 & 1997 \\
\hline Sri Lanka & 15.3 & 2000 & 92 & 2000 & 3.7 & 2002 & 7.8 & 2000 & 11.6 & 00/02 & 2.1 & $00 / 02$ \\
\hline Thailand & 23.0 & $95-00$ & 44 & 2000 & 3.0 & 1999 & 16.2 & 1999 & 19.2 & 1999 & 22 & 1999 \\
\hline Singapore & 4 & $95-00$ & 30 & 2000 & 14.0 & 2001 & 44.5 & 2003 & 58.5 & 2003 & 29 & 2001 \\
\hline Switzerland & 5 & $95-00$ & 7 & 2000 & 36.2 & 2002 & 85.8 & 2000 & 122.0 & 2000 & 60 & 2002 \\
\hline
\end{tabular}

Table 2 Economic cost of Tsunami on health system [World Bank (WB), 2005]

\begin{tabular}{|c|c|c|c|c|c|c|c|}
\hline Country & $\begin{array}{l}\text { Total damage } \\
\text { and losses } \\
\text { (US\$ million) }\end{array}$ & $\begin{array}{l}\text { Health sector } \\
\text { damage and } \\
\text { losses } \\
\text { (US\$ million) }\end{array}$ & $\begin{array}{l}\text { Total } \\
\text { reconstruction } \\
\text { needs } \\
\text { (US\$ million)* }\end{array}$ & $\begin{array}{l}\text { Health sector } \\
\text { reconstruction } \\
\text { needs } \\
\text { (US\$ million)* }\end{array}$ & $\begin{array}{l}\text { Health sector } \\
\text { needs as \% of } \\
\text { total needs* }\end{array}$ & $\begin{array}{l}\text { Total WB funding, } \\
\text { US\$ million } \\
\text { (received/pledged) }\end{array}$ & $\begin{array}{l}\text { Theoretical } \\
\text { percentage of } \\
\text { WB funding to } \\
\text { health sector } \\
\text { (out of received/ } \\
\text { out of pledged) }\end{array}$ \\
\hline India & 1022.8 & Over 15.7 & 1213.0 & Over 11.0 & $0.9 \%$ & $465 / 528.5^{\dagger}$ & $2.4 / 2.1 \%$ \\
\hline Indonesia & 4500.0 & 91.9 & n.a. & n.a. & n.a. & $0 / 500^{*}$ & n.a. \\
\hline Maldives & 470.0 & 5.6 & 304.2 & 12.2 & $4.0 \%$ & 14 (over 3 years) & $87.1 \%$ \\
\hline Sri Lanka & C 1000.0 & 60.0 & C 1500.0 & 84.0 & $5.6 \%$ & $35 / 150$ & $240 / 56 \%$ \\
\hline Thailand & n.a. & n.a. & n.a. & n.a. & n.a. & n.a. & n.a. \\
\hline
\end{tabular}

*Recovery 'needs' refer to the public sector's; use of the term 'costs' would include costs that might be repaid by private insurances

${ }^{\dagger}$ Asian Development Bank/World Bank funding

*Pledge by the Multi-Donor Trust Fund

n.a.- not applicable

reconstruction are estimated to be at least that much. ${ }^{10}$ In the Maldives, where the total cost of damages was $\$ 470$ million, $\$ 5.6$ million of those losses were incurred by the healthcare sector and the estimated health sector reconstruction costs are in the order of $\$ 12.2$ million. ${ }^{11}$

\section{LOAD ON THE HEALTHCARE SECTOR}

Although none of the epidemic outbreaks that were reasonably predicted by the World Health Organization (WHO) actually occurred, the load imposed on healthcare services was high for many other reasons. The first of these was the number of injuries that required treatmentestimated by WHO as about 500000 in the region. ${ }^{2}$ In Thailand, hospitals in the affected areas recorded 10000 patients in the two weeks following the Tsunami. Of these,
2233 required hospital admission and 1254 needed major surgery. 398 patients had to be placed in intensive care. ${ }^{12}$ In Phangnga, the emergency department of the local general hospital recorded an intake of 986 patients on 26 December alone, and in the week that followed, 2285 trauma cases were managed and 683 surgical interventions performed. ${ }^{23}$ In India, more than 1135 injuries were reported by Cuddalore hospital in the 15 days following the Tsunami. ${ }^{14}$ The surgical load in Indonesia was so acute that some amputations are reported to have been performed without anaesthesia, ${ }^{15}$ and the subsequent demand for artificial limbs exceeded the capacity of the formal healthcare system to provide the necessary psychological counselling. Most orthopaedic-injury patients in Sri Lanka had to be transferred to Colombo, the capital, because hospitals ran out of external fixator equipment (Steinmann pins and 
Kirschner wires) and because the only other location with sufficient capacity was the Jaffna Teaching Hospital in the Tamil-held area of the country. ${ }^{16}$

In addition to the injuries that placed a huge burden on healthcare services, local hospitals had to deal with periodic but short-lived increases in diseases such as viral fevers and diarrhoeal infections. ${ }^{17}$ Although these often followed seasonal trends and were ultimately controlled, the fear of epidemic outbreaks required many of them to be monitored with laboratory/epidemiological investigations that were often costly and difficult to arrange. ${ }^{1}$

One of the more complex loads on both health facilities and healthcare personnel was the handling and identification of large numbers of dead bodies. In Thailand, Indonesia and Sri Lanka few hospitals had enough refrigerated mortuary space and the psychological burden on healthcare staff called on to improvise facilities and identify bodies led to serious problems of 'burn-out' and depression. ${ }^{1}$ In Thailand, pressure from the media and from the families of tourists ( $43 \%$ of the Tsunami victims in Thailand were foreigners) $)^{18}$ who arrived seeking some type of closure on their relatives presented an additional load on already overworked and stressed healthcare personnel. ${ }^{1}$ The handling of bodies was also complicated by misconceptions about the disease potential they posed; many healthcare personnel wrongly thought there was a high risk of disease transmission. ${ }^{19-21}$

Management of excess patient load was facilitated in some countries by evacuation to other hospitals. In Thailand and Sri Lanka, which had pre-existing disaster management plans, secondary and tertiary care institutions further inland were quickly able to upscale their intake capacity and accommodate patients transported from the coastal areas. $^{22,23}$ By day three after the Tsunami, the health authorities in Thailand had been able to organize the evacuation of at least 1000 patients (103 Thais and 898 foreigners) to these hospitals. ${ }^{12}$ In the Maldives, the transfer (by boat and air taxi) of patients to the main hospital in Male was also operational three days after the Tsunami. ${ }^{4}$ In Indonesia, on the other hand, the load quickly exacerbated pre-existing deficiencies in the healthcare system in Aceh, and options for evacuation to other hospitals were very limited.

Throughout this period there were also patients who fell 'outside the formal net' of assistance. The assumed, albeit not proven, presence of large numbers of Burmese unregistered migrant workers in Thailand remained a concern. It was difficult to determine what their needs were or might be, ${ }^{1}$ and much of the work with unregistered migrant workers was left to non-governmental organizations (NGOs) that were more familiar with them. ${ }^{24}$ Independent media and NGO sources suggest that, out of 250000 Burmese legal and illegal workers in the six provinces, 2500-3000 died and 5000-7000 are still missing. ${ }^{25,26}$

In Somalia, political instability (insecurity) and inaccessibility (poor condition of roads) along the coastline hit by the Tsunami were obstacles to any rapid assessments, and even today the extent of the damage to the health sector remains unclear. ${ }^{27}$ There are, nevertheless, reports that many of the needs of the people in the area were met by pre-existing emergency supplies that had been placed in the country. ${ }^{28}$

\section{EXTERNAL SUPPORT}

The magnitude of the disaster was matched by a relief effort that brought more than six hundred agencies together with material assistance, personnel and funds. By June 2005, almost $\$ 12$ billion had been pledged to the relief effort, and contrary to experience in previous disasters, the followthrough on pledged assistance was high. ${ }^{29}$ In May 2005, WHO alone reported that it had already received contributions of $\$ 42.5$ million and had firm pledges of an additional $\$ 15.4$ million. ${ }^{30}$

Despite all the efforts made by the national governments of affected countries, it is unlikely that much progress would have been achieved without this rapid influx of external medical and emergency health assistance. Around 130 foreign relief organizations arrived in the region within two weeks of the disaster and set up mobile field hospitals, deployed emergency healthcare staff, procured and distributed medical supplies, and established vaccine and cold-chain systems. ${ }^{1}$ The rapid introduction of well-drilling equipment, water desalination plants and other water and sanitation equipment by these external groups was probably one of the key factors that helped avert the epidemic outbreaks that had been predicted. ${ }^{31}$

In India, the government decided early that it could manage without external medical personnel support, but elsewhere the assistance was sometimes overwhelming. In Sri Lanka, the arrival of foreign personnel was massive and at one point the offer of an additional 700 expatriate medical personnel led national health authorities to ask international groups to stop sending staff; 1,32 two of the larger international NGOs modified their plans and activities when they realized that local staff were plentiful, well trained and capable of doing more than the NGOs had anticipated. ${ }^{32,33}$

In the Maldives, where large numbers of foreign staff likewise arrived, the Ministry of Health commented that some relief personnel did not seem technically prepared for the task and had less expertise even than nationals who had not been trained in emergency work. ${ }^{4}$ Indeed, in some of the countries, expatriate staff came to be seen as a hindrance to the national effort because they usually 
required housing, were difficult to coordinate, and often had personal and professional needs that could not be easily met.

As in previous disasters, the donations that were received by countries varied in both relevance and quality. Unmarked and time-expired medicines were reported by some countries, and in others there were contributions of food that could not be used. Indonesian rice-eating populations were sent wheat donations that often went uneaten, ${ }^{14}$ and in Southern India some areas received precooked food that people did not know how to use. ${ }^{35}$ In Thailand, there was concern about the impact indiscriminate distribution of powdered milk might have on breastfeeding. ${ }^{36}$ In Indonesia, there were also reports that far more prosthetic appliances were received than were required at the time. ${ }^{37}$ On the whole, however, lessons seem to have been learned from previous disaster responses, and WHO guidelines on drug donations, for example, appear to have been heeded more than in the past. ${ }^{38}$

\section{CIVIL/MILITARY COOPERATION}

Throughout the region, the military proved indispensable to the relief effort. National and foreign militaries helped civilian relief teams to reach people in outlying areas that had been cut off and they also played a vital role in evacuating people in need of emergency medical care. In Indonesia, to which over 30 countries sent military teams, the Australians and the Germans set up field hospitals that had operating rooms and a capacity for acute care, and their helicopter transports permitted staff and materials, as well as patients, to be flown in and out of difficult-to-reach areas. ${ }^{39}$ Thus despite the many misunderstandings that often seem to plague collaboration with the military in humanitarian relief operations, the interventions of national and expatriate military forces appear to have been well received by national authorities and international organizations everywhere.

\section{COORDINATION}

Coordination of internal and external relief operations in both man-made and natural disasters is always problematic, especially in disasters that attract large numbers of external groups. Both UN agencies and NGOs often have difficulty in sharing information and in conducting joint assessments and planning. ${ }^{40}$ This is partly because organizations tend to arrive with different mandates and expectations as well as having different methods of working. The competition for funds and visibility also seems to limit their willingness to coordinate or be coordinated.

The number of NGOs, bilateral government and UN agencies and intergovernmental organizations working in health sector operations in response to the Tsunami was high. In Indonesia there were 116, in Sri Lanka 129, in Thailand 77, and in the Maldives $54 .{ }^{41}$ Coordinating the arrival and work of so many organizations, their staff, equipment, procurement and shipments, became a challenge for ministries of health, many of which did not have suitable staff in sufficient numbers. In addition, the task of coordinating people, ideas, materials, and donations, and then evaluating ongoing needs, was often made more arduous because of the unwillingness of external groups to submit to centralized coordination. ${ }^{1}$

\section{CONCLUSIONS}

The impact of the Tsunami will be felt by healthcare systems in the region for years to come. Physical infrastructure damage was massive but in some countries the loss of human resources was an even greater calamity. The rebuilding and re-equipping of clinics and hospitals may well be guaranteed by monetary donations, but the task of replacing staff will be much more daunting. In some cases, the loss of staff may be compensated by healthcare reforms that allow primary health care staff to do more than would otherwise have been the case. In the Maldives, for example, the Tsunami highlighted the potential hazards of dependency on expatriate staff, and could lead to a re-evaluation of the role that existing well-trained staff such as community health workers and nurse-midwives can play in the delivery of services.

The psychosocial burden on healthcare staff in all the Tsunami-affected countries, especially those with exceptionally high numbers of fatalities, will also merit follow-up. What many of them were called on to do exceeded all previous experiences and expectations, and the physical as well as psychological burn-out among them was considerable.

Although the value of external assistance was obvious, the competence of some of the people who arrived in countries as 'experts' calls for attention. Personnel who do not bring essential skills are often a burden to nationals who have to accommodate them and address their needs. In the future much will be gained by strengthening the capacity of ministries of health to prepare for such challenges, including how to coordinate external inputs. Much more should also be done by international agencies and NGOs to ensure that the capacities of receiving countries are respected and where necessary strengthened, and that the right type of people are sent on relief missions.

The response to the Tsunami also highlighted the importance of advance planning for emergencies. In Thailand and Sri Lanka the evacuation of badly injured patients was facilitated by procedures that had been prepared and discussed before the Tsunami. While these were not always perfect or widely known, they did offer a 
framework for decision-making. In view of the susceptibility of the region to other types of disasters, similar initiatives merit development elsewhere.

Acknowledgments We thank the participants of the ICMH Tsunami Expert Review Committee meeting that took place in Male, Maldives, 22-24 April and the Taiwan International Health Operations Center and others for their support of this project.

\section{REFERENCES}

1 International Centre for Migration and Health. Interim Report of a Meeting on Public Health Impact of the Tsunami. Geneva: ICMH, 2005

2 Center of Excellence in Disaster Management and Humanitarian Assistance. Indian Ocean Earthquake \& Tsunami Emergency Update [http:// www.coe-dmha.org/Tsunami/Tsu052505.htm]. Accessed 25 May 2005

3 Country presentation, Republic of Indonesia. The Health Aspects of the Tsunami Disaster in Indonesia. Conference on Health Consequences of the Tsunami, Phuket, Thailand, 4-6 May 2005 [http:// www.who.int/hac/events/tsunamiconf/presentations/1_2_national_ perspectives_indonesia_idrus_ppt.pdf]. Accessed 9 June 2005

4 Affal A. National Report, Health Sector Response. ICMH Expert Review Meeting. Male, Maldives 22-24 April 2005. Geneva: ICMH, 2005

5 Ministry of Public Health. Center of Disease Surveillance and Health Relief after the Tsunami Disaster, Ministry of Public Health Thailand, Evaluation of Damage concerning the Ministry of Public Health, March 2005. Nontaburi: MoH Thailand, 2005

6 Perera MALR. SrO ICMH Expert Review Meeting. Male, Maldives, 22-24 April 2005. Geneva: ICMH, 2005

7 Bappenas and World Bank. Indonesia: Preliminary Damage and Loss Assessment [http://siteresources.worldbank.org/INTINDONESIA/ Resources/Publication/280016-1106130305439/damage_assessment. pdf]. Accessed 9 June 2005

8 Bappenas and World Bank. Indonesia: Notes on Reconstruction [http:// siteresources.worldbank.org/INTINDONESIA/Resources/ Publication/280016-1106130305439/reconstruction_notes.pdf]. Accessed 9 June 2005

9 Asian Development Bank, United Nations, World Bank. Sri Lanka Preliminary Damage and Needs Assessment [http://siteresources. worldbank.org/INTSRILANKA/Resources/233024-1107313542200/ SLNA0205Final-E.pdf]. Accessed 9 June 2005

10 Asian Development Bank, United Nations, World Bank. India Post Tsunami Recovery Program Preliminary Damage and Needs Assessment. 8 March 2005 [http://www.worldbank.org.in/WBSITE/EXTERNAL/ COUNTRIES/SOUTHASIAEXT/INDIAEXTN/0,, contentMDK: 20390890 pagePK:141137 piPK:141127 theSitePK: 295584,00.html]. Accessed 9 June 2005

11 Asian Development Bank, United Nations, World Bank. Republic of the Maldives Tsunami Impact and Recovery Assessment [http:// siteresources.worldbank.org/INTMALDIVES/Resources/mv-na-full02-14-05.pdf]. Accessed 9 June 2005

12 Kunaratanapruk S. Thailand National Health Perspectives on the Tsunami Crisis. Conference on Health Consequences of the Tsunami. Phuket, Thailand, 4-6 May 2005
13 Wattanawaitunechai C, Peacock SJ, Jitpratoom P. Tsunami in Thailand - disaster management in a district hospital. N Engl J Med 2005;352:962-4

14 Nath L, Voluntary Health Association of India. Tsunami Report. ICMH Expert Review Meeting. Male, Maldives, 22-24 April 2005. Geneva: ICMH, 2005

15 Beller GA. Where high-tech medicine was irrelevant. J Nucl Cardiol $2005 ; 12: 143-4$

16 Calder J, Mannion S. Orthopaedics in Sri Lanka post-tsunami. J Bone Joint Surg 2005;87:759-61

17 United States Center for Disease Control and Prevention. Rapid health response, assessment, and surveillance after a tsunami. MMWR 2005;54:61-4 [http://www.cdc.gov/mmwr/preview/mmwrhtml/ mm5403al.htm]. Accessed 31 May 2005

18 Mail and Guardian online. Victim's remains found five months after tsunami, Bangkok, Thailand, 19 May 2005 [http://www.mg.co.za]. Accessed 8 June 2005

19 Conolly E, Moore M. Missing could be in mass graves. The Age.com [www.theage.com.au/news/Asia-tsunami]. Accessed 21 June 2005

20 Iype G. My sons might be there in burial ground. Rediff.com [http:// www.rediff.com/news/2004/dec/28iype.htm]. Accessed 21 June 2005

21 Ball P. Mass graves not necessary for Tsunami victims, rapid burial to avert health risks is a myth. Nature.com [http://www.nature.com/ news/2005/050103/pf/050103-10_pf.html]. Accessed 21 June 2005

22 Watts J. Thailand shows the world it can cope alone. Lancet 2005;356:284

23 Perera R, Sri Lanka Ministry of Health, Nutrition and Welfare. Tsunami Expert Review: Sri Lanka. ICMH Expert Review Meeting. Male, Maldives, 22-24 April 2005. Geneva: ICMH, 2005

24 Doctors of the World. Reports from the field: helping migrants from Burma access care, June 2005 [http://www.doctorsoftheworld.org/ projects/thailand.cfm]. Accessed 30 June 2005

25 Deutche Press Agentur (DPA). Burmese tsunami victims ignored at home, abroad, Phuket, Thailand. Relief Web, 8 Jan 2005 [http://wwwnotes. reliefweb.int/w/rwb.nsf.6686f45896f15dbc852567ae00530132/ bc10abf075a9e055c1256f8300380428?OpenDocument]

26 Hakoda T. Invisible Victims of Tsunami-Burmese Migrant Workers in Thailand. Human Rights, Osaka, March 2005 [http://www. hurights.or.jp/asia-pacific/039/03.htm]. Accessed 15 June 2005

27 World Health Organization. Health action in Crisis Highlight No. 3622 November 2004: Somalia [http://www.who.int/disasters/repo/ 15234.pdf]. Accessed 1 June 2005

28 United Nations Office for the Coordination of Human Affairs. Earthquake and Tsunami OCHA Situation Rep. No. 32. 18 March 2005 [www.undp.org/bcpr/disred/documents/tsunami/ocha/sitrep32.pdf]. Accessed 14 June 2005

29 Large T. Analysis - big tsunami donors rank poorly in generosity. Reuters, 24 June 2005 [http://www.alertnet.org/thenews/newsdesk/ L23032450.htm]. Accessed 30 June 2005

30 World Health Organization. Funds given/pledged to WHO for the Indian Ocean Tsunami response, 16 May 2005 [http://www.who.int/ $\mathrm{hac} / \mathrm{crises} /$ international/asia_tsunami/appeal/ tsunami_contributions/en.htm]. Accessed 13 June 2005

31 Treerutkuarkul A. Tsunami response was no disaster. Bangkok Post 5 May 2005

32 Riley J, Dowdy ZR. Long term aid a concern. Newsday.com [http:// www.newsday.com/mynews/ny-wotsun0105,0,313564.story]. Accessed 9 June 2005

33 Médecins Sans Frontières. Asian Tsunami, Overview of MSF Activities in Sri Lanka, January 2005 [http://www.msf.org/msfinternational/ invoke.cfm?objectid=B8B82DD2-A30E-41EC-AA527898054DE334\& component $=$ toolkit.report\&method $=$ full_html]. Accessed 7 June 2005 
34 Stokoe P. Indonesia National Report. ICMH Expert Review Meeting. Male, Maldives, 22-24 April 2005. Geneva: ICMH, 2005

35 AFP. World Leaders gather for post-tsunami, aid pledges near $4 \mathrm{bln}$ dlrs. Political News [http://www.political-news.org/breaking/4759/ world-leaders-gather-for-post-tsunami-summit-aid-pledges-near-4-blndlrs.html]. Accessed 16 June 2005

36 Baby Milk Action. Press release: 'Responses to the Tsunami disaster and infant feeding', 13 January 2005 [http://www.babymilkaction.org/ press/press13jan05.html]. Accessed 10 June 2005

37 Aceh \& Sumatra Utara Tsunami Disaster Crisis Information Center. Aceh Receives Oversupply of Prostheses [http://www.acehtsunami.org/ index.php?option $=$ com_content\&task $=$ view\&id $=126 \&$ Itemid $=39]$. Accessed 14 June 2005
38 Carballo M, Serdarevic D. Responding to Emergency Drug Needs: Lessons for the Future. Geneva: ICMH, 1996

39 Channel News Asia. Unlikely coalition of the willing wins crucial tsunami relief battles. Media Corp News, 24 January 2003 [http:// www.channelnewsasia.com/stories/afp_asiapacific/view/128823/1/. html]. Accessed 9 June 2005

40 WHO Regional Office for South-East Asia. The Tsunami and After: Emergency doctor says $W H O$ has key role in health crises [http:// www.who.int/bulletin/volumes/83/2/interview0205/en/print. html]. Accessed 9 June 2005

41 Reliefweb. 14 February 2004 [http://www.reliefweb.int/library/ documents/2005/rw-ind-14feb.pdf]. Accessed 14 June 2005 